\title{
Lost, Dysfunctional or Evolving? A View of Business Schools from Silicon Valley
}

\author{
Kyle Eischen ${ }^{+}$ \\ keischen@ucsc.edu
}

\author{
Nirvikar Singh* \\ boxjenk@ucsc.edu
}

October 2005

\begin{abstract}
Recent articles have rekindled discussions around the direction and relevance of US business schools. The two main viewpoints are distinct but equally critical. On one hand, business schools are considered overly focused on "scientific research" and having lost their connection to "real world" and management issues. On the other hand, schools are considered "dysfunctionally" focused on media rankings and short-term superficial marketing fixes. Our study of educational opportunities and workforce development in Silicon Valley suggests a different viewpoint. We agree that both approaches correctly identify the challenge of preparing managers in globalized world. However, we believe they misdiagnose the cause of the failure. Rather than being lost or dysfunctional, we believe business programs - like the firms and students they serve - are in the process of evolving to meet a shifting global and local environment. Our findings indicate that business schools face structural, content, and program shifts. Educationally, business programs continue to be seen as doing a good job of educating their students in core functional areas and processes. However, they do less well in teaching their graduates interpersonal skills, real-time decision-making, recognition of contexts, and integration across functional areas. These are increasingly the skills demanded by the global business environment. Even more challenging is meeting the demand for both sets of skills within very specialized fields like technology management. Structurally, new types of students and learning demands are placing stresses on traditional full-time two-year programs and their business models. Women and minority groups increasingly form the majority of the future student population, with distinct needs and demands for part-time and executive education. This shift is also evident in demands for life-long learning and engagement as opposed to a fixed, one-shot program experiences. These challenges require business schools to build upon what they do well, while innovating to serve new business and student needs.
\end{abstract}

Keywords: management education, Silicon Valley, globalization, technology

JEL codes: I23, M00, L80, R11

\footnotetext{
${ }^{+}$Research Associate, Center for Global, International \& Regional Studies, University of California, Santa Cruz, and Lecturer, Department of Sociology, Santa Clara University

* Professor of Economics, University of California, Santa Cruz
} 


\section{Introduction}

Recent articles have rekindled earlier discussions ${ }^{1}$ around the direction and relevance of US business schools. The main viewpoints are distinct but equally critical. On one hand, Bennis and O’Toole have criticized business schools as overly focused on " "scientific' research", losing their connection to "real world" and management issues. ${ }^{2}$ On the other hand, DeAngelo, DeAngelo and Zimmerman center their criticism on business schools as "dysfunctionally" focused on media rankings and short-term superficial marketing fixes. ${ }^{3}$ Both viewpoints do agree that "business as usual" leads management programs towards irrelevance, and fails to provide students with the skills required by a global business environment. However, because business schools are framed as either too abstractly academic or too responsive to short-term market demands (so “damned if you do, damned if you don't”), the question of how to evolve to better prepare managers remains an open question.

Our recently completed year-long study of educational opportunities and workforce development in Silicon Valley suggests a different viewpoint. ${ }^{4}$ We agree that both types of critique correctly identify the challenges of preparing managers in globalized world. However, we believe they misdiagnose the cause of the failure. Rather than lost or dysfunctional, we believe business programs - like the firms and students they serve — are in the process of evolving to meet a shifting global business environment. The key questions are how is the environment shifting and how should business schools adapt to these changes? The rest of this paper addresses exactly this dynamic, seeking to understand how business schools can build upon what they do well, while innovatively adapting to serve new business and student needs.

We begin by outlining overall trends in the management education market, highlighting the strong and continued growth in the demand for management education as well as the proliferation of business schools. A key aspect of this growth is the establishment of the two-year MBA program as both a US national and global standard for management education. This standardization, led by leading brand programs, extends also to the content and methods of management education. Paired with this however, is the increasing diversity of programs both in terms of educational niches and part-time or executive programs.

We then focus on identifying central shifts facing business programs: structural demand shifts, education content issues and program structure. Educationally, business programs continue to be seen as doing a good job of educating their students in basic functions and processes. In contrast to the arguments of an overly academic focus, business schools do provide students with strong functional tool-sets (finance, marketing, accounting etc) that have real value in the businessworld. However, they do less well in teaching their graduates interpersonal skills, real-time

\footnotetext{
${ }^{1}$ See for example: Pfeffer and Fong, 2003; Management Education Task Force, 2002; Doctoral Faculty Commission, 2003; and The Economist, 2004.

${ }^{2}$ Bennis and O’Toole, 2005.

${ }^{3}$ DeAngelo, DeAngelo, and Zimmerman, 2005.

${ }^{4}$ Singh, Akella and Eischen, 2005. The research involved program analysis, literature reviews, academic and business interviews and an online survey. Nationally, we conducted 47 interviews at seven leading management programs. In Silicon Valley, we interviewed 20 executives, including several CEOs of smaller companies, and “C” and next-level executives of large corporations. We are grateful to our colleague, Ram Akella, for his help in arranging and conducting many of the interviews. The survey contacted 415 UCSC Alumni self-identified in management/technology positions in Silicon Valley and generated an 8\% response rate.
} 
decision-making, recognition of contexts, and integration across functional areas. These are increasingly the skills demanded by the global business environment. Even more challenging is meeting the demand for both sets of skills within very specialized technology sectors as exist in innovation-driven regions like Silicon Valley.

Structurally, new types of students and learning demands are placing stresses on traditional fulltime two-year programs and their business models. Women and minority groups increasingly form the majority of the future student population, with distinct needs and demands for part-time and executive education. This shift is also evident in demands for life-long learning and engagement as opposed to a fixed, one-shot program experiences. Shifting resources and program structures to meet these needs is problematic for well-established programs. In part this is due to simple bandwidth constraints of both faculty and facilities. More seriously, it suggests a path-dependence derived from ties to very specific industries and easy growth as demand for degrees have grown.

The final section views these trends through a consideration of Silicon Valley evolving business and workforce needs given existing management education infrastructure. The aim is to understand how the above shifts both challenge and create opportunities for management education. Finally, we summarize key findings and conclude with some final thoughts on how management education and business schools may evolve.

\section{Trends and Shifts in Management Education}

Over the course of year, our interviews with academics at leading management schools, Silicon Valley executives, analysis of ranking methodologies, literature reviews, and a survey of UCSC alumni all confirmed the same message: business schools do what they do very well; however it is not sufficient to meet the complex challenges of the current global market for either business or students. Executives lauded MBA training from a narrow functional perspective (accounting, finance, marketing, etc.), but found that the ability to integrate knowledge across functional areas, and to deal with diverse groups of people across organizational boundaries and cultures, was not particularly well taught. Executives and recruiters routinely emphasized the importance of interpersonal skills of all kinds, and leadership and critical decision-making skills in particular. An equally consistent theme, given our focus in Silicon Valley was the importance of these aspects for global business in highly innovative or technically advanced fields.

One hypothesis, reflected in the current debates, is that institutional inertia, a narrow focus on media rankings, and the economic pull of traditionally high paying jobs in financial services and management consulting may be combining to prevent emerging demands from being fully recognized and met. Yet, macro-level viewpoints of the demand for management education suggest that the MBA as traditionally defined is doing well (see Table 1). 
Table 1: MBA Degrees Granted 1987 to $2002^{5}$

\begin{tabular}{lccc} 
Degrees Awarded & \multicolumn{3}{l}{} \\
\hline Year & MBA Degrees & Change & $\%$ Change \\
\hline $1986-87$ & 67,093 & 404 & $0.61 \%$ \\
$1987-88$ & 69,230 & 2137 & $3.19 \%$ \\
$1988-89$ & 73,065 & 3835 & $5.54 \%$ \\
$1989-90$ & 76,676 & 3611 & $4.94 \%$ \\
$1990-91$ & 78,255 & 1579 & $2.06 \%$ \\
$1991-92$ & 84,642 & 6387 & $8.16 \%$ \\
$1992-93$ & 89,064 & 4422 & $5.22 \%$ \\
$1993-94$ & 93,437 & 4373 & $4.91 \%$ \\
$1994-95$ & 93,809 & 372 & $0.40 \%$ \\
$1995-96$ & 93,982 & 173 & $0.18 \%$ \\
$1996-97$ & 97,619 & 3637 & $3.87 \%$ \\
$1997-98$ & 102,171 & 4552 & $4.66 \%$ \\
$1998-99$ & 108,085 & 5914 & $5.79 \%$ \\
$1999-00$ & 112,258 & 4173 & $3.86 \%$ \\
$2000-01$ & 116,475 & 4217 & $3.76 \%$ \\
$2001-02$ & 120,785 & 4310 & $3.70 \%$ \\
\hline \hline
\end{tabular}

Our research suggests that a more plausible explanation is that the shifts just now becoming visible in Silicon Valley suggest that the typical United States MBA curriculum may be better meeting the demands of the US corporation of the 1970s or 80s rather than those of the global, entrepreneurial firms that seem to arise in Silicon Valley. One examples of such market inertia is visible in data on MBA enrollments, where the most established and highest-ranking schools continue to support the largest full time programs as well as extreme selectivity. ${ }^{6}$

It is also fair to emphasize that management schools, by their nature, all try to be extremely customer focused, and they are attempting to address changes in demand. Rather than a weakness, this seems a positive response to both student and business demands. The real issue is the flexibility and effectiveness of such changes both within the US broadly and in specific locations like Silicon Valley. European schools, for example, with different traditions, a more global perspective, and less inertia by virtue of later entry, may be somewhat more successful in offering curricula appropriate to current workplace demands. On the other hand, in the United States, the continued difficulty in attracting and enrolling women and minorities in MBA programs is an indication that existing management schools may face structural impediments to serving new market segments, as well as the changing needs of traditional business school customers.

A central issue for the evolution of management education is to understand the distinct demand shifts occurring that challenge existing programs. In many respects, these challenges arise from the need to adapt successful management education models within a much more competitive, diverse and global market. Management education is perceived as providing value to both students and business. However, as the demands upon students and businesses have increased, so too have the demands on business schools beyond the well-established core skill-sets, research agendas and educational methods.

\footnotetext{
${ }^{5}$ Source: National Center for Education Statistics.

${ }^{6}$ Business Week. MBA Business Schools and Profiles, 2004.
} 


\subsection{Structural Demand Shifts}

Overall economic trends and past evolution have affected the demand for management education. Increased globalization, greater industry-level competition, and more rapid innovation have all increased uncertainty and competition in the job market, affecting both the rewards (higher potential payoffs) and the risks (greater obsolescence) of management education at the graduate level, contributing to cyclical fluctuations in demand among those who are already employed.

On a macro-level, industries and occupations that graduates are pursuing seem to be fairly stable (see Figure 1). However, underneath these categories are extraordinary market, technology and occupational shifts. This is especially visible in the dynamic regional economy of Silicon Valley, where both management and technology skills are easily out-dated. This drives the need for continual education, but also influences the structure of such education.

\section{Figure 1: Employment and Occupational Placements of MBA Students ${ }^{7}$ Employment by Industry \\ Occupatlonal Breakdown}
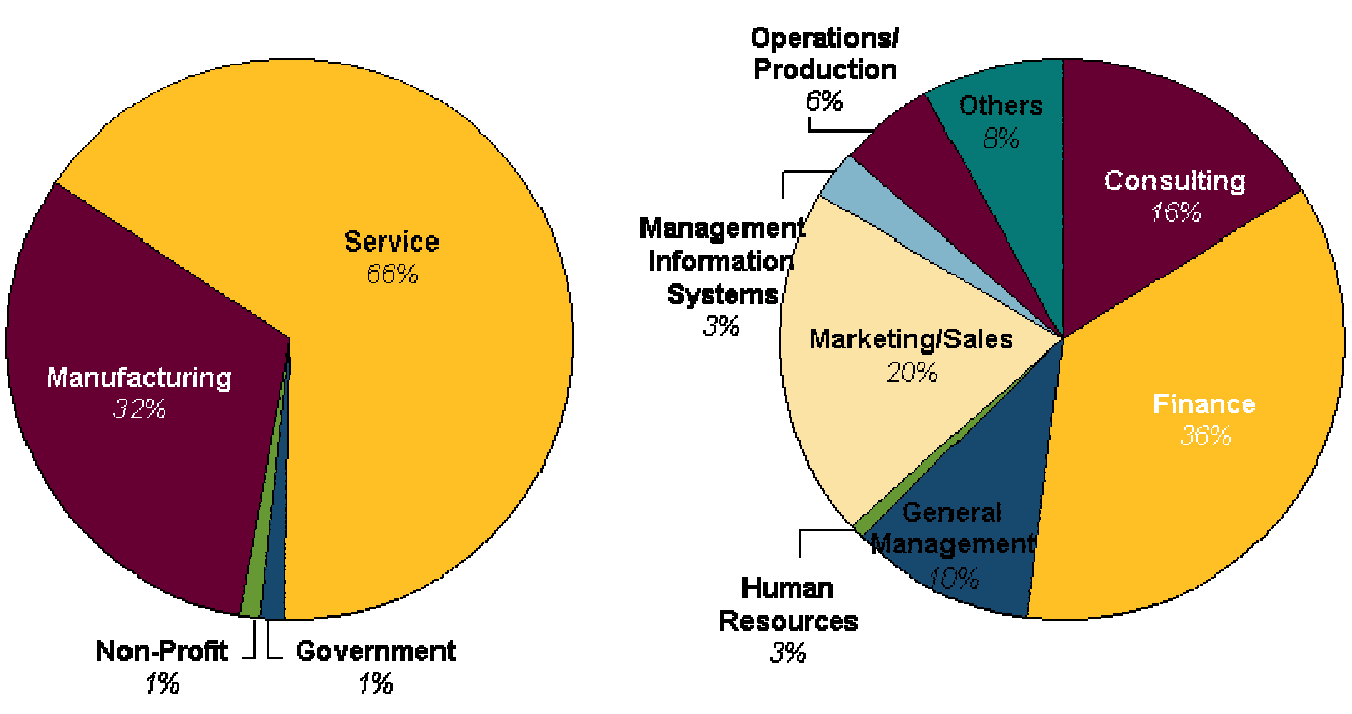

Workers increasingly need to upgrade their skills, and are more likely to change employers and career paths, perhaps even several times over their careers. While the economic returns to all kinds of higher education have increased, the costs of acquiring the needed education through traditional methods have also increased, since tuition increases have substantially outstripped inflation. Students are more likely to pursue higher education while they hold down a job, to avoid the high opportunity cost of going to college. This is increasingly common at the undergraduate level as well as at the graduate level. MBA-granting schools have responded to this demand by offering more, and more varied, part-time and evening/weekend programs. Also, there are an increasing number of shorter courses offered by universities, private for-profit providers and corporations themselves: these are all designed to meet the increased demand for continual learning offered in a relatively efficient manner.

\footnotetext{
${ }^{7}$ Source: US News and World Report, 2004. Aggregate of top 50 schools.
} 
The increased importance of technology and greater volume of information in the workplace, the higher science and technology content of products, and the need to work across national and cultural boundaries have all had impacts on the demand for education in general, and management education in particular. Students are very aware of trends, and are eager to prepare themselves for changes in the workplace. This is quite clearly demonstrated by undergraduate majors entering graduate management programs nationally (as shown in Figure 2), with over a third having undergraduate degrees in engineering or science.

\section{Figure 2: Undergraduate Major of Management School Entrants ${ }^{8}$ \\ Aggregate Undergraduate Major}

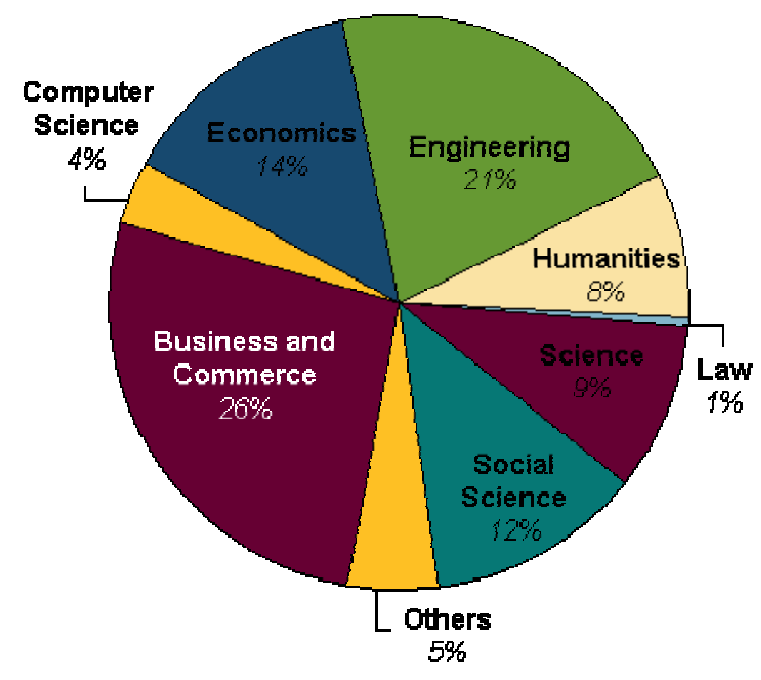

Our interviews with executives in Silicon Valley all emphasized the importance of globalization and the need for flexibility and speed in management decision-making. Technology executives in Silicon Valley who did not have formal management education were particularly critical of MBA programs, but the perception that business schools might be missing something was common across a wider set of interviewees. Our interviews with faculty at leading management schools provided similar perspectives on what is being demanded, but at the same time, several faculty members suggested to us that institutional inertia has slowed down the change in curricula that meet the current demands of firms.

\subsection{Content}

As indicated above, MBA programs are almost uniformly perceived as providing solid training in basic analytical techniques in the core functional areas. Graduates of these programs (especially the higher ranked ones where we interviewed faculty) all have a toolkit of techniques and scenarios that appears to be quite uniform. This situation reflects the success of the postwar program of creating management education with a solid analytical foundation. What is taught in MBA programs is what can be taught well in the classroom, using standard methods of

\footnotetext{
${ }^{8}$ Source: US News and World Report, 2004. Aggregate of top 50 schools.
} 
explaining concepts and techniques, posing problems (often through case studies), and guiding the students in working out solutions, typically in teams. As noted, the cost of applying this template has been a certain rigidity and limitation in thinking (inability to "think outside the box," to use a phrase that was used by one executive - clichéd but capturing the situation), at least as perceived by some of the executives we interviewed.

Certainly, there have been attempts to create specializations that cross disciplinary boundaries and promote integrative thinking. Two prime examples are strategy and entrepreneurship, both of which have special significance for firms in Silicon Valley. Each of these illustrates the general tensions in management education, in very different ways. Strategy as a separate subject area is not emphasized by all management schools, since it is not really a functional specialization in the manner of finance or marketing. However, departments of strategy have tended to move away from providing integrative approaches to emphasizing a particular theoretical approach, that of game theory, as a way of providing rigor and systematic analysis. Certainly, these are important qualities, but this also reflects the trend toward the strong analytical background as well as the demands of relevant faculty to have academic publications in a well-defined field. As our research suggests, the move away from an integrative approach may not always be consistent with the goal of preparing successful managers for the modern business world.

In the case of entrepreneurship, a unifying conceptual paradigm has not emerged, and the subject is not really one that has the status of an academic field. Nevertheless, one can argue that there is a set of common features that defines management in entrepreneurial settings, including innovation and growth, special kinds of financial issues, and leadership and team building. Therefore, to some extent, a successful entrepreneurship specialization can potentially correct some of the perceived weaknesses in MBA programs. It can be, and has been argued that all managers need to be more entrepreneurial in the modern business environment, and this perspective may be a useful one in assessing potential market niches in management education. It is also clear that the seeds of entrepreneurial training - leadership and team work as two examples - do exist within business schools already. The challenge is combining these with a broader set of skills, institutional support and rigor. ${ }^{9}$

An equally important development has been incorporating into management education the spectacular rise of information technology (IT) in the workplace. There is general agreement that IT has a significant role across functional areas in business strategy, in maintaining parity of costs and service levels. The end of the Internet boom has turned attention to technology more broadly, particularly toward the bio-info-nano cluster. In some respects, this is a return to earlier times, when technology management was an important concern during the United States' push for a global lead in science and technology during the Cold War. Many schools are now looking to revitalize their technology management programs. This push is in part prompted by the demands of businesses, which as one executive put it, need "people who combine MBA (know ROI, business plans, real options and portfolio management, project management, strategy, etc.), Information Systems (know CRM, ERP, XML, etc.), and Organizational Change (know ethnographic approaches, organizational change, etc.) into one person.” These efforts are often in collaboration with engineering schools or divisions.

\footnotetext{
${ }^{9}$ See an interesting discussion in Chafkin, 2005 around the difficulty of matching broader support for entrepreneurship programs with academic rigor and business experience.
} 
Two other aspects of management education content that emerged are worth mentioning. A complement to pure functional specialization is domain or industry specialization. Thus, an individual may wish to be trained in issues that are salient in, or specific to financial services, media, entertainment, hardware, software, pharmaceuticals and biotechnology, aerospace, health care, transportation, or some other sector or industry. Interviews with executives indicate that this kind of education is important, though not necessarily in a dominant fashion, i.e., not to the detriment of core functional area knowledge. Business schools have dealt with this need by creating industry-focused, interdisciplinary research centers, without disturbing the functional and departmental organization of curricula and faculty careers. Interviews with business school faculty indicated that these efforts are reasonably successful.

On the other hand, as indicated earlier, the "softer" or less functionally defined skills, such as interpersonal communication, leadership, negotiation and teamwork are absolutely paramount in the minds of executives and therefore of corporate recruiters. While these skills may not be amenable to quantitative analysis and not so easily taught in the classroom (several executive interviewees emphasized the importance of innate abilities and on-the-job learning), there are some fields that offer useful approaches to systematic training. To some extent, the issue of "softer" skills is linked with teaching methods because simulations and experiential learning may be more important in these cases.

\subsection{Teaching Methods and Programs}

Two very different methods are used for teaching management within management programs. The first is the conventional academic lecture style, where concepts and techniques are presented in lecture formats, and students engage in individual and group problem-solving in assignments and examinations. The second is the case study method, where students are presented with real or disguised business scenarios, asked to analyze the issues involved for management decisionmakers, and make recommendations, through group and individual study, and classroom discussion. Ideally, case analysis will also require students to apply quantitative methods learned in basic lecture courses, such as calculations of returns on investment, present values, sensitivity of quantitative projections to different assumptions on risk, and so on. In fact, executives we interviewed (at least those who had opinions on this topic) thought that MBAs were generally well trained in this type of contained, well-defined analysis.

However, they also strongly indicated that typical MBA graduates are not able to combine their analytical tool-kit and case study experience to engage very readily in creative problem-solving, decision-making in new situations, or innovative thinking. Such concerns were strongly felt given the innovative and dynamic cycles in Silicon Valley with, as one respondent put it, "Fresh MBAs often lament that trying to apply their insights and techniques to a real Silicon Valley company is like trying to eat Jell-O with a fork.” Some executives we spoke to suggested that there was not enough diversity within the cases used in MBA programs. One management school faculty member suggested that cases are not updated frequently enough, with long lags in new cases being adopted. Executives repeatedly emphasized the importance of experiential or on-thejob learning, and understanding of context. There are at least two avenues for dealing with this shortcoming, and management school education has followed both of them, but to a degree that 
seems inadequate for the needs of employers. The two approaches are simulations within an academic setting, and experiential learning through projects and internships in actual workplaces.

Simulations can be thought of as role-playing exercises. They can be an extension of the case study approach, which also requires students to put themselves in the shoes of actual decisionmakers. There is now tremendous scope for using information technology to provide experience in integrative decision-making in areas such as strategy. For example, computer simulations allow student teams to form virtual firms competing against other firms in real-time. Some management school faculty we interviewed suggested that this approach is a victim of slow adoption in their institutions, even though role playing games have become commonplace for entertainment, and even for military training. An alternative example of academic simulation, one that typically is conducted outside of the regular curriculum, is the relatively recent phenomenon of business plan competitions. These are often sponsored by outside organizations, and involve several tiers of competition. They require students to create "real-world" business plans that are judged by expert panels of industry practitioners and financiers.

Experiential learning has always been a part of management education, within the form of summer internships between the two years of the typical MBA program. Executives we interviewed who commented on this suggested that the usual internship also falls short, because it does not give the intern real decision-making responsibilities that would affect the bottom line of the company. This is obviously a difficult problem to overcome. Successful internships require considerable faculty and company involvement, particularly in terms of guidance and mentoring. As in the case of simulation methods that cannot use information technology to manage the process (e.g., negotiation, business plan competitions), the labor-intensity of the process makes scaling up difficult or costly. Group projects in firms, as part of the academic curriculum, generally require less resources and incentives, but in all these cases, high investments are required by management school faculty and administrations to provide highquality experiential learning.

What is clear is that traditional programs, even if modified through new teaching methods, create barriers to meeting new business demands. Clearly, part-time programs and EMBAs are most suitable for integrating classroom and on-the-job learning. For example, an EMBA program can require its students, who continue to work through the program, to individually devise projects that they know will be of relevance to their company, and to obtain the cooperation of colleagues. This approach can be implemented even in basic functional courses. This highlights an advantage of such programs over the two-year full-time program, aside from the lower opportunity cost and risk involved of not having to quit one's job.

\subsection{Delivery and Location}

The conventional MBA model involved students taking two years off from work, typically in their late twenties, attending a university program full-time, and then either returning to their employer, or shifting firms or industries. Depending on personal constraints, an individual might seek a program near their current location, but the main driver for those taking such a major step in career investment and realignment has been the reputation of the program. This reputation would typically be gauged by media rankings. Thus the premier programs in the United States or 
Europe attracts students from all over the world through students relocating to the main program location. ${ }^{10}$

The combination of increased competition in supply and the changing economics of demand indicated above have meant that more and more management schools are adjusting their delivery methods to overcome locational constraints that their prospective students may face. Top-ranked programs such as Harvard, MIT and Stanford are less interested in this adjustment strategy, but even very highly ranked programs such as Wharton and Columbia have taken steps in this direction. In some cases, this may lead to an urban school reaching out to suburban areas, e.g., NYU in Westchester County. Schools with strong reputations have extended their locational diversification to attractive locations beyond their own geographical regions. Two important examples of this are Wharton West, based in San Francisco, and Columbia's joint venture with UC Berkeley's Haas School, which spans both coasts. Both of these efforts offer EMBA programs designed to tap into new geographic markets that are perceived as underserved by local schools. Part-time and evening/weekend MBA programs may be offered in satellite campuses, particularly where the main campus is not located in a convenient urban area. EMBA and shortcourse executive education programs can also pursue this locational strategy. Where short courses are customized for specific firms, the company site is a natural delivery point. Some management schools have extended this locational reach by establishing satellite campuses in other countries, with or without local partners.

One other important aspect of the locational issue to emphasize is the relative popularity of parttime and EMBA programs with women and minority students. Consistently over the last five years, application type and enrollments in leading MBA programs has shifted toward part-time and executive programs, and when such applications are broken down by type, there is clearly greater demand by female and minority students (See Figure 3). There is an obvious logic connecting location and part-time and EMBA programs, exactly because of the time and mobility limits of full-time employees. More importantly, the broader issue raised is the need for restructuring program resources - infrastructure, professors, courses - to meet new student demands away from core areas. Like the discussion of content above, such locational shifts challenge institutional support, academic rigor, faculty engagement and cost-effectiveness.

\footnotetext{
${ }^{10}$ On the other hand, there are very well regarded programs that serve mainly regional demand pools. Examples of such regional programs include UC Davis and UC Irvine within the UC systems, and Ohio State (Fisher), Purdue (Krannert) and Vanderbilt (Owen) nationally.
} 


\section{Figure 3: EMBA Applications and Enrollments by Market Segment ${ }^{11}$}

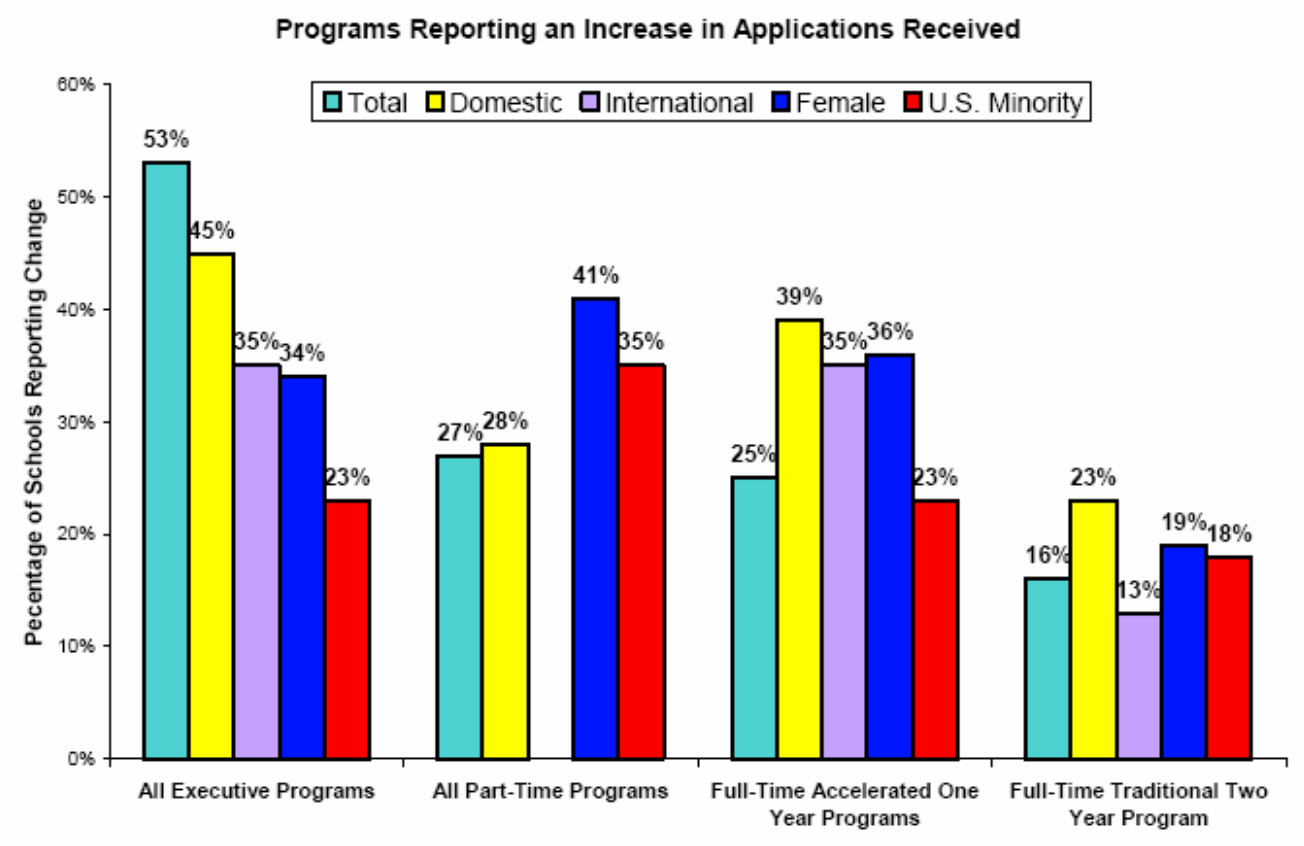

Figure 2. Positive Change in Application Volume for Specific Applicant Subgroups, Shown by Program Type

An alternative approach to overcoming distance is to use information technology. The Internet provides the technical means, and the falling cost of bandwidth has made this approach economically more attractive. Schools like MIT, which do not maintain multiple delivery locations, do use information technology selectively, to bring students into the classroom via interactive videoconferencing technology. This approach is still in its infancy, and is probably subject to limits in scaling up, but it is bound to increase in the future, though it will never replace actual delivery based on physical proximity. The reason for that prediction is, of course, the well-recognized benefits of social-network-building that traditional MBA programs afford.

Overall, management schools’ approach to delivery is characterized as creating diversified locational portfolios. This parallels the programmatic diversification that has taken place with respect to the timing and length of instruction, as well as content. Thus, management schools offer an increasingly complex and broad product mix, designed to compete effectively with rivals, and to attract previously underserved market segments.

\section{The Silicon Valley Case: The Regional Economy and Workforce Development Needs}

Given the overall shifts in management education given above, what is the role of existing or new business programs in preparing a regional economy and workforce? Our research focused on this exact question within Silicon Valley, considering both existing management education offerings and the emerging transformation of the regional economy in the next decade.

\footnotetext{
${ }^{11}$ Source: Graduate Management Admission Council, 2004.
} 
Silicon Valley is currently recovering from a "double whammy": the end of a national economic boom, and the end of an extensive build out of Internet infrastructure. These cyclical effects are compounded by longer-term secular changes in the nature of work that is capable of being performed abroad. "Offshoring” is the more accurate term to apply to these latter trends, rather than the more typical "outsourcing" with different implications for employment, innovation and investment in "captive" offshoring versus outsourcing to foreign locations. Silicon Valley is constantly subject to these forces, as a high cost region even within the US, as well as a center of innovation and technology services.

The implications of the secular trend are that Silicon Valley is in a phase of "reinventing" itself, as it has done periodically in the past. ${ }^{12}$ The region is distinguished by the high number of smaller firms that are engaged in innovation. This was especially apparent during the Internet boom, when the number of venture-funded startups increased dramatically. While one is unlikely to see a repeat of that kind of situation in our lifetimes, it is clear that the ethos of seeking the next "new new thing” remains a central part of Silicon Valley. The robustness of the area's venture capital community is a significant contributor to this environment and mindset.

One can therefore predict that Silicon Valley will transform itself in the next decade. ${ }^{13}$ It will retain its focus on cutting edge technologies, as well as organizational innovations. Given the high cost of living and working in the region, the jobs created there must be those that have high value added. The engine of growth for the region will continue to be innovation, and the creation of innovative firms. This regional economic transformation underlies the demands for many of the shifts in management education outlined above.

\subsection{Workforce Development Needs}

To the extent that many routine manufacturing and service jobs will leave Silicon Valley as a result of cost compulsions for firms, it is important to conceptualize what kinds of jobs might replace them. Given both the regional environment and future growth trends, it is quite clear that growth will most likely occur in services with strong ties to existing regional strengths. With the increased complexity of the legal system, strains on environmental resources, expanded global ties through immigration, and increasing science and technology content of products and services, one can predict that those jobs will increase in numbers which require deep knowledge of local context, flexibility of response to stochastic shocks, and understanding of what people need and want to get by in their daily lives. Thus, as indicated in Table 2, all kinds of specialized professional services will expand as a fraction of the workforce, but particularly those service occupations linked to the business lifecycle in Silicon Valley.

\footnotetext{
12 Joint Venture Silicon Valley, 2002.

${ }^{13}$ Silicon Valley Manufacturing Group, 2004.
} 
Table 2: Regional Capabilities and Prospects for Occupations ${ }^{14}$

\begin{tabular}{|c|c|}
\hline $\begin{array}{l}\text { Bay Area Competitive } \\
\text { Strengths }\end{array}$ & Sample Occupations Aligned With Regional Capabilities \\
\hline $\begin{array}{l}\text { New Business Creation and } \\
\text { Entrepreneurship }\end{array}$ & $\begin{array}{c}\text { Venture capitalists, lawyers and entrepreneurial } \\
\text { infrastructure }\end{array}$ \\
\hline \multirow{3}{*}{$\begin{array}{c}\text { Research In Advanced } \\
\text { Technologies } \\
\text { AND } \\
\text { Cross-disciplinary Research }\end{array}$} & IT, biotech and nanotech R\&D professionals \\
\hline & $\begin{array}{c}\text { Select computer and software engineers for research and } \\
\text { advanced development (e.g., architects, systems level } \\
\text { software engineers, software engineers with domain } \\
\text { expertise) }\end{array}$ \\
\hline & $\begin{array}{c}\text { Select engineering including electrical, mechanical and } \\
\text { electronics }\end{array}$ \\
\hline \multirow{2}{*}{$\begin{array}{l}\text { Concept And Market } \\
\text { Development }\end{array}$} & Strategic managers in sales and marketing \\
\hline & Product marketing managers \\
\hline $\begin{array}{l}\text { Global Integrated } \\
\text { Management }\end{array}$ & $\begin{array}{c}\text { Managers of global teams and assets (headquarters, product } \\
\text { development, IT, HR, etc.) }\end{array}$ \\
\hline
\end{tabular}

One important aspect of specialized professional services arises when an organization is involved, rather than individuals acting independently. Thus, a single lawyer may operate just with secretarial assistance. However, a large law firm may require individuals (who may or may not be lawyers) to perform coordination and internal resource allocation roles, or in other words to act as managers. Thus, one can predict that management jobs will increase in number and change in scope. One has already seen that classic middle managers have been downsized as a result of the corporate re-engineering of the 1990s: information technology and improved internal communication made this possible just as increased competition made it necessary for firms to go this route of flattening hierarchies. One can argue that this trend will accelerate. At the same time, having an organization whose work may span several continents, cultures and time zones requires new kinds of managers and management skills. Thus one can speculate that these kinds of jobs will proliferate. Table 3 provides further data on state-level projections by job category.

\footnotetext{
${ }^{14}$ Source: A.T. Kearney, 2004.
} 
Table 3: California Occupation Employment Projections $2002-2012^{15}$

\begin{tabular}{|c|c|c|c|}
\hline Occupational Titles & $\begin{array}{l}\text { Numerical } \\
\text { Change }\end{array}$ & $\begin{array}{l}\text { Percent } \\
\text { Change }\end{array}$ & $\begin{array}{l}\text { Percentage } \\
\text { of All New } \\
\text { Jobs }\end{array}$ \\
\hline Total, All Occupations & $2,691,700$ & $18.6 \%$ & \\
\hline Management Occupations & 167,900 & $21.4 \%$ & $6.24 \%$ \\
\hline Top Executives & 52,500 & $19.5 \%$ & \\
\hline $\begin{array}{r}\text { Advertising, Marketing, Promotions, Public Relations, and Sales } \\
\text { Managers }\end{array}$ & 25,200 & $28.4 \%$ & \\
\hline Operations Specialties Managers & 39,200 & $21.4 \%$ & \\
\hline Other Management Occupations & 50,900 & $20.8 \%$ & \\
\hline Business and Financial Operations Occupations & 148,000 & $23.0 \%$ & $5.50 \%$ \\
\hline Business Operations Specialists & 102,400 & $24.9 \%$ & \\
\hline Financial Specialists & 45,600 & $19.6 \%$ & \\
\hline Computer and Mathematical Occupations & 130,300 & $32.9 \%$ & $4.84 \%$ \\
\hline Computer Specialists & 129,100 & $33.8 \%$ & \\
\hline Mathematical Scientists & 1,200 & $8.8 \%$ & \\
\hline Architecture and Engineering Occupations & 38,300 & $11.6 \%$ & $1.42 \%$ \\
\hline Engineers & 21,800 & $10.4 \%$ & \\
\hline Total Management \& Technical Jobs & 484,500 & & $18.00 \%$ \\
\hline
\end{tabular}

Essentially the scientists, engineers, entrepreneurs and venture capitalists that drive innovation are crucial to creating the high-end management jobs envisaged in a successful re-invention of Silicon Valley. Thus the conditions are needed that support the right ecosystem for this scenario to play out. Undoubtedly, while the United States is an incredibly mobile society, and people come to Silicon Valley from all over the world, it is important to provide local educational opportunities for those who are going to be entering this changing labor market.

The United States, especially California, and Silicon Valley most of all, have always been dynamic economies. Technological change and globalization have both accelerated in 1980s and even more in 1990s. A jobless recovery, the movement of a wider variety of jobs offshore, the global spread of technology, manufacturing skills and managerial know-how, flexibility of business models and organizational structures all point in the direction of a careful evaluation of workforce needs. Our research indicates that managerial and other high-end service jobs will be part of any successful re-invention of Silicon Valley and the Bay Area, and that management education has a crucial role to play in providing education and training that impart the necessary skills and knowledge.

\footnotetext{
${ }^{15}$ Source: State of California, 2004.
} 


\subsection{Identified Management Education Market Needs}

As suggested above, and at the risk of some oversimplification, one can assert that the US management education model has been very market driven; producing MBAs with expertise in areas where the financial rewards have been greatest in the last decade. Students with specializations in finance, strategy and marketing have been popular hires in high-paying professions such as investment banking and consulting, and in old-line corporate America. However, two weaknesses of particular importance to Silicon Valley, linked to the popularity and demand of these market segments, emerged from our industry and faculty interviews. First, US schools appear to be relatively weak in international business. In addition, technology, information systems and operations were considered to be relatively neglected in US management schools, again reflecting a tendency to "follow the money."

These perceived weaknesses reflect a gap between the current demands of Silicon Valley firms and the strengths of business programs and students. Silicon Valley executives indicated that firms require managers with skill sets that are only partly provided by MBA programs. As would be expected, opinions varied according to the position and experience of the interviewee. For example, executives with educational backgrounds purely in technology-related fields, overlaid with experiential learning of management practices and techniques, were least enthusiastic about MBA program graduates. They were sometimes skeptical of the ability to learn the needed skills through formal education, emphasizing on-the-job learning instead.

To complement the semi-structured interviews with executives, we conducted a web survey of UCSC alumni with management positions in Silicon Valley. Some of these results are reported in Tables 4 and 5 , and are quite consistent with the messages of the executive interviews. They also provide some finer-grained information on different aspects of the perceived strengths and weaknesses of management education as seen from a Silicon Valley viewpoint.

\section{Table 4: Top Ten Existing Management School Program Aspects Considered Excellent $^{16}$}

\begin{tabular}{llc}
\hline Rank & Category & $\begin{array}{c}\text { Percentage } \\
\text { Response } \\
\text { "Excellent" }\end{array}$ \\
\hline 1 & Economic analysis & $32 \%$ \\
2 & Connecting techniques to case studies & $29 \%$ \\
3 & Operations research & $23 \%$ \\
4 & Information systems management & $22 \%$ \\
5 & Risk management & $21 \%$ \\
6 & Leadership and motivation & $21 \%$ \\
7 & Venture finance & $17 \%$ \\
8 & Government regulation & $15 \%$ \\
9 & High-tech marketing & $15 \%$ \\
10 & Public policy analysis & $14 \%$ \\
\hline
\end{tabular}

\footnotetext{
${ }^{16}$ Source: UCSC Alumni Survey.
} 
Executives with MBAs were more appreciative of the skills such programs impart. In particular, they noted the ability of MBAs to do basic technical analyses, such as rate of return or net present value calculations. At least one senior executive stressed the importance of having MBA graduates who are extremely well versed in quantitative techniques. It was also noted that there is a diversity of management jobs, and the skill set required can vary across specialties. It is, perhaps, a measure of the success of the standard MBA program curriculum that analytical skills that might have been scarce a generation ago are now taken for granted. The ubiquity of powerful spreadsheet software has also clearly played a role in raising the bar in this respect. Interestingly, even though such software has helped level the playing field, in terms of basic analysis, across graduates of MBA programs with very different rankings and reputations, executives still preferred to hire from highly ranked programs, because of their selectivity and increased likelihood of getting someone with high ability.

\section{Table 5: Top Management School Program Aspects Considered Good or Excellent $(70 \%+\text { positive response })^{17}$}

\begin{tabular}{llc}
\hline Rank & Category & $\begin{array}{c}\text { Percentage } \\
\text { Response } \\
\text { "Good" or } \\
\text { "Excellent" }\end{array}$ \\
\hline 1 & Financial Engineering & $93 \%$ \\
2 & International finance & $88 \%$ \\
3 & Project management & $87 \%$ \\
4 & Managing services businesses & $86 \%$ \\
5 & Connecting techniques to current business problems & $86 \%$ \\
6 & Product manufacturing & $85 \%$ \\
7 & Public policy analysis & $85 \%$ \\
8 & Government regulation & $85 \%$ \\
9 & Internet marketing & $83 \%$ \\
10 & Human resource management & $83 \%$ \\
11 & Connecting techniques to students' experience & $82 \%$ \\
12 & Technology management & $79 \%$ \\
13 & Supply chain management & $75 \%$ \\
14 & Entertainment industry management & $74 \%$ \\
15 & Operations research & $72 \%$ \\
15 & Information systems management & $72 \%$ \\
16 & High-tech marketing & $71 \%$ \\
\hline
\end{tabular}

Technology executives in Silicon Valley all emphasized the importance of creativity and innovativeness in management. This is perhaps unsurprising, given the entrepreneurial nature of Silicon Valley firms. These aspects of management were also highlighted by some nontechnology executives, who suggested that MBA graduates might be limited by their training, and unable to handle decision-making in unfamiliar contexts. With respect to technology management, executives in technology-centric firms suggested that MBA programs were not adequate in addressing the specific mix of technology understanding and market awareness required for successful development and market deployment of innovative products.

\footnotetext{
${ }^{17}$ Source: UCSC Alumni Survey.
} 
Two other themes, pertaining to management more broadly, came across strongly in the executive interviews. First, executives emphasized the need for managers with strong interpersonal skills, including communication in cross-cultural contexts, and overall leadership abilities. They further emphasized the changing nature of firms, with flatter hierarchies and more interactions across firm boundaries, the implications for management and leadership being a greater need for positive motivation and collaborative approaches, rather than top-down instructions or hierarchical delegation. It was implicit (and sometimes explicit) in executive comments that MBA graduates were not sufficiently imbued with the requisite skills in this dimension. The survey results provide complementary supporting data on this perspective (see Table 6).

The second theme, closely related to aspects of the first, was the globalization of business, in a manner different from earlier decades. A Harvard faculty interviewee characterized it as vertical rather than the older horizontal globalization, meaning that firms now may have significant portions of their value chains handled in multiple countries, whether under common ownership or outsourced, rather than just replicating production facilities in different countries (the traditional multinational firm model). The implications of this geographic shift overlap with demands for new management, leadership and interpersonal skills sets. As one executive indicated "management by walking around" is no longer feasible given global, distributed operations.

\section{Table 6: Top Ten Most Valued Management Skills and Management School Perceived Quality of Offerings ${ }^{18}$}

\begin{tabular}{|c|c|c|c|c|}
\hline Rank & Category & $\begin{array}{l}\text { Percentage } \\
\text { Response } \\
\text { "Important" }\end{array}$ & $\begin{array}{l}\text { Percentage Who } \\
\text { Think Existing } \\
\text { Offerings Are } \\
\text { Good or } \\
\text { Excellent in } \\
\text { This Area }\end{array}$ & $\begin{array}{l}\text { Percentage } \\
\text { Who Think } \\
\text { Existing } \\
\text { Offerings Are } \\
\text { Excellent in } \\
\text { This Area }\end{array}$ \\
\hline 1 & $\begin{array}{l}\text { Interpersonal } \\
\text { communication }\end{array}$ & $76 \%$ & $53 \%$ & $5 \%$ \\
\hline 2 & Ethics & $73 \%$ & $56 \%$ & $6 \%$ \\
\hline 3 & $\begin{array}{l}\text { Cross-cultural } \\
\text { management }\end{array}$ & $70 \%$ & $50 \%$ & $6 \%$ \\
\hline 4 & Negotiation & $70 \%$ & $53 \%$ & $0 \%$ \\
\hline 5 & $\begin{array}{l}\text { Leadership and } \\
\text { motivation }\end{array}$ & $67 \%$ & $58 \%$ & $21 \%$ \\
\hline 6 & Project management & $66 \%$ & $83 \%$ & $6 \%$ \\
\hline 7 & $\begin{array}{l}\text { Technology } \\
\text { management }\end{array}$ & $63 \%$ & $71 \%$ & $6 \%$ \\
\hline 8 & R\&D management & $62 \%$ & $59 \%$ & $6 \%$ \\
\hline 9 & Risk management & $62 \%$ & $57 \%$ & $21 \%$ \\
\hline 10 & Business forecasting & $60 \%$ & $61 \%$ & $11 \%$ \\
\hline
\end{tabular}

${ }^{18}$ Source: UCSC Alumni Survey. 
In sum, the Silicon Valley executives indicated that firms are facing a rapidly changing context, one that is evolving in a manner not seen in the United States before this, certainly since the advent of formal management education. Two types of overlapping needs emerged from the interviews. First, a targeted program that would provide training in the management of innovation processes toward successful commercialization (including an integrated approach to research, product development, manufacture and marketing across national and national boundaries), and a broader management program, which would subsume the above skills and ideas in a broader theme of "global high tech management."

\subsection{Responses and Trends in Existing Offerings}

The trends we identified are fairly widely recognized, and management schools, which are extremely customer focused, have been moving toward serving these needs. As discussed above, several top management schools have tried to add formal or informal international components to their MBA programs. EMBA programs, in particular, may be held at sites spanning more than one country, giving senior managers a global perspective through this locational diversification, and through attracting a geographically more diverse set of participants. There has also been a revival of interest in technology management programs (as opposed to MBAs), though these remain somewhat of a niche market and do not address global issues to the degree indicated by Silicon Valley executives

\section{Figure 4: Silicon Valley Graduate Management Program Enrollment Shares by Type $^{19}$}

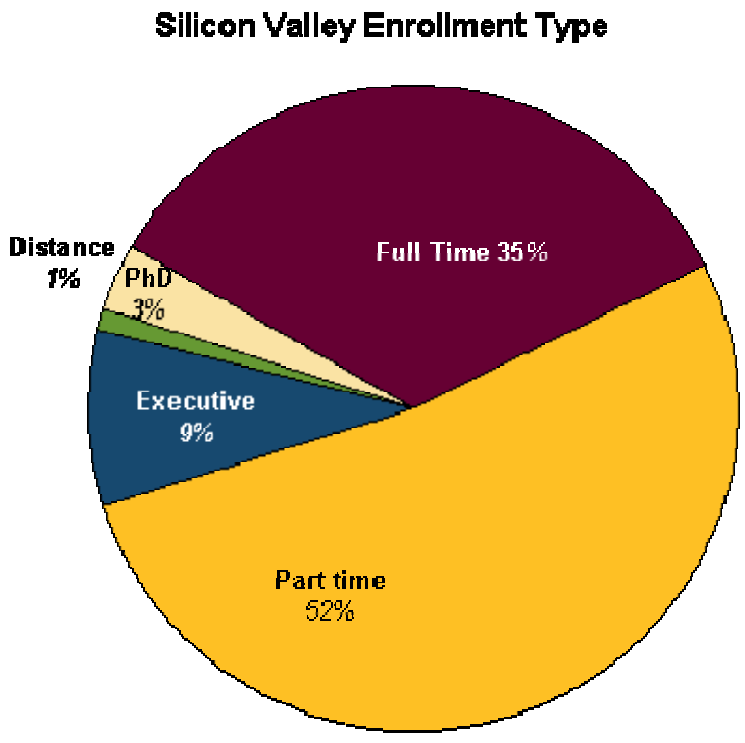

Analyzing regional management offerings revealed tendencies to respond to both general shifts and Silicon Valley needs. However, it was evident that responses to the needs of businesses came first and foremost from administrators responsible for bottom line performance, with faculty having to be given incentives to innovate or modify their approaches. In this respect, locational, timing and other delivery adjustments are easier to achieve than innovations in

\footnotetext{
${ }^{19}$ Business Week, 2004.
} 
curriculum, and this is what seems to have been happening (as evidenced in Figure 4). As such, while efforts are being made, they are often only partial, resulting in a continued perception of weakness in business program offerings. Additionally, without full support from faculty such offerings also lack the rigor, brand and breadth that are crucial to meeting the complex demands placed upon them.

To some extent, it is also the case that Silicon Valley firms, especially those in high tech areas, are not fully representative of the MBA market in general. To the extent that corporations such as General Motors, Proctor and Gamble, Wal-Mart, Morgan Stanley and McKinsey are the main employers of MBAs, Silicon Valley, with a heavy sprinkling of entrepreneurial firms, and strong emerging ties with Asia in high tech, may have needs that are somewhat different from mainstream corporate America. However, this is only true to the extent that the general management shifts visible in Silicon Valley — deepening globalization, offshoring, workforce diversity, and accelerated competition and innovation cycles — are unique to the region.

\section{Conclusions}

Our analysis in Silicon Valley indicates firms are facing a rapidly changing context, one that is evolving in a manner not seen in the United States before, certainly since the advent of formal management education. This regional shift mirrors more fundamental shifts facing business schools generally. Management education, after evolving into a standardized, established, and widely recognized field, with the MBA degree as the flagship qualification, is now on the cusp of significant change. Management schools are already responding to changes in demand by differentiating themselves through specialization, improving the level of service to students, and trying to reach global markets more effectively and efficiently. These efforts have been undertaken largely by administrators trying to meet the demands of business in a globalized, dynamic marketplace.

On the other hand, teaching methods and content, which require heavier faculty involvement in change, are responding more slowly to demand-side trends. The current globalization of business, in particular, is a trend that has not found its way fully into management school curricula. Another important area where curricular change has lagged is in instilling management students with an understanding of technological innovation and its consequences for business. Of course, these issues are well-recognized by management schools, and they are attempting to overcome their inertia. Teaching methods in management schools have also lagged in incorporating technology to enhance learning through simulation of real-world problems that go beyond conventional case studies. Part of the structural inertia existing programs may face in attracting women or minorities is their emphasis on full-time programs. Considering increases in program demand across various segments of the potential student population, it is quite clear that program offerings significantly shape applicant pools.

In the specific case of Silicon Valley, there are two implications for management education in the region. First, there is a niche for a technology management program that provides training in the management of innovation processes toward successful commercialization. A second opportunity lies in management education that is focused not just on high tech, but centers on the increasing globalization of Silicon Valley's business, all through the value chain. Most 
importantly, it is perceived that there is insufficient focus on preparing managers for operating in globalized, cross-cultural contexts, and there do not appear to be many management schools in the United States that address this in a significant manner. The globalization of high tech value chains, in particular, makes this aspect complementary to a focus on technology.

It also emerged from interviews that leadership and interpersonal skills are insufficiently addressed in graduate management education. There are certainly limits to what can be achieved in traditional classroom settings in providing these skills, but there is scope for more effective use of simulations, whether technology-based or otherwise, to improve education in these dimensions. A related aspect that was perceived as lacking in management education, but highly valued in Silicon Valley, was creativity. Clearly, creativity is also difficult to teach, but expanding management education beyond a standardized set of case studies may yield some improvements. Careful recruitment and selection of students may also be important in this respect. There are also important lessons from programs outside of business schools, particularly in engineering, that have had success teaching creativity, design and innovation management. ${ }^{20}$

From the perspective of workforce needs, it emerged that management schools have not been as successful as they might have liked in recruiting women and under-represented minorities into their graduate programs. One issue here may be the historical culture of management schools, mirroring the traditional culture of corporate America. Given the diversity and heterogeneity of Silicon Valley firms, this seems to represent an opportunity for innovative programs. Even more significant, however, is the need for programs to align resources and content to meet these emerging market demands. Clearly, this is not a simple process, presenting issues of rigor, bandwidth and cost to any program. However, it is also arguable that such investments, if carefully considered, could support the demands for creating more relevant, effective and diverse management education in a global marketplace.

Finally, our research suggests that some of the current debate may be too one-dimensional to provide real guidance on the best future direction of graduate management education.

Our interviews with industry executives, survey, and discussions with business school faculty, all suggested that there is a well-recognized range of issues facing business schools, covering the content, delivery methods and objectives of management education. The next step is moving beyond this general definition of the core challenges to consider how such issues can be addressed. In this light, perhaps one important idea that emerges from our research is the need for business schools to pay closer attention to their customers' customers - i.e., those business leaders who are shaping their organizations' responses to the changing global economy.

\footnotetext{
${ }^{20}$ Singh, Akella \& Eischen, 2005. One particularly strong Silicon Valley example is Stanford's Engineering School, which has been a central contributor to Stanford's reputation as source of innovation and entrepreneurship.
} 


\section{REFERENCES}

Alsop, Ronald. “The Full-Time Advantage”. Wall Street Journal/Harris Interactive Report: Top Business Schools. Wall Street Journal. September 21, 2005.

A.T. Kearney. The Future Of Bay Area Jobs: The Impact Of Offshoring And Other Key Trends. 2004.

Bennis, Warren G. and James O’Toole. “How Business Schools Lost Their Way”. Harvard Business Review, May $1^{\text {st }} 2005$.

Business Week. MBA Business Schools and Profiles. September 2004.

http://www.businessweek.com/bschools/04/.

Chafkin, Max. “The Best Jobs That Nobody Wants”. Inc. Magazine. September 2005:

http://www.inc.com/magazine/20050901/b-schools.html

College Journal from the Wall Street Journal. The WSJ Guide to Business Schools 2005. http://www.collegejournal.com/reports/bschool05/.

DeAngelo, Harry, Linda DeAngelo, and Jerold Zimmerman. "What's Really Wrong With U.S. Business Schools?", July 2005. http://ssrn.com/abstract=766404

Doctoral Faculty Commission. Sustaining Scholarship in Business Schools: Report of the Doctoral Faculty Commission to AACSB International's Board of Directors Executive Summary. AACSB International, September 2003. http://www.aacsb.edu/dfc.

Doctoral Faculty Commission. Sustaining Scholarship in Business Schools: Report of the Doctoral Faculty Commission to AACSB International's Board of Directors. AACSB International, September 2003. http://www.aacsb.edu/dfc.

The Economist. The Debate about Management Education. May 20, 2004. http://www.economist.com/business/globalexecutive/education/displayStory.cfm?story_id=2685 892.

Financial Times. Business Life/ MBA Rankings. http://news.ft.com/businesslife/mba.

Gilbert, Nedda. The Princeton Review Best 143 Business Schools. 2005 Ed. New York, NY:

Random House, 2004.

Graduate Management Admission Council. Application Trends Survey 2004: Executive Report. Graduate Management Admission Council, 2004.

http://www.gmac.com/gmac/ResearchandTrends/SurveyResearch/ApplicationTrendsSurvey.htm.

Joint Venture Silicon Valley. Preparing for the Next Silicon Valley: Opportunities and Choices. Joint Venture Silicon Valley, June 2002. http://jointventure.org. 
Management Education Task Force. Management Education at Risk: A Report from the Management Education Task Force Executive Summary. AACSB International, April 2002. http://www.aacsb.edu/publications/metf

National Center for Education Statistics. "Degrees and Other Awards Conferred by Institutions of Higher Education: 2001-2002”. US Department of Education. http://nces.ed.gov/

Pfeffer, Jeffrey and Christina T. Fong. "The End of Business Schools? Less Success Than Meets the Eye.” Academy of Management Learning and Education 1, no. 1(September 2002): 78-95

SiliconValley.com. Silicon Valley 150. 2004.

www.siliconvalley.com/multimedia/siliconvalley/archive/sv150_03.pdf.

Silicon Valley Manufacturing Group. PROJECTIONS: Silicon Valley 2005. September 23, 2004. http://www.svmg.org/Events/Projections.

Singh, Nirvikar, Ram Akella and Kyle Eischen. Educational Opportunity and Workforce Development Study, Report to the Chancellor's Office. University of California, Santa Cruz, March 2005.

State of California. Occupational Outlook for 2002-2012. Employment Development Department, Labor Market Information Division. December $8^{\text {th }}, 2004$. http://www.labormarketinfo.edd.ca.gov/

US News \& World Report. America’s Best Graduate Schools 2005: Top Business Schools. Premium Ed. 2004.

http://www.usnews.com/usnews/edu/grad/rankings/mba/brief/mbarank_brief.php. 